\title{
Model-Eliciting Activities Approach as a Tool to Improve Creative Thinking Skills and Self- Confidence
}

\author{
Nihdayati Pane \\ Department of Mathematics Education, Post Graduate School \\ Universitas Negeri Medan \\ North Sumatera, Indonesia \\ nihdapane@gmail.com \\ Edi Syahputra \\ Department of Mathematics Education, Post Graduate School \\ Universitas Negeri Medan \\ North Sumatera, Indonesia \\ Mulyono \\ Department of Mathematics Education, Post Graduate School \\ Universitas Negeri Medan \\ North Sumatera, Indonesia
}

\begin{abstract}
The Model-Eliciting Activities (MEAs) approach is a reality-based approach, works in small groups and presents a model to help students build problem solving and get students to apply an understanding of the mathematical concepts which they have learned. The main adventages of MEAs to develop student's thinking then students can create their own models to solve mathematical problems. The purpose of this study is to test influence of the MEAs learning approach on student's craetive thinking skills and self-confidence. This study is a quasiexperimental research using pre-test and post-test control group design. The data in this research were analyzed using Two Ways ANOVA using SPSS 17.0 for windows. Results of Two Ways ANOVA shows that the MEAs approach has significant value gained 0.000 and 0.012 which are less than 0.05 . This means that $\mathrm{H}_{0}$ refused and $\mathrm{H}_{1}$ accepted so there is influence of MEAs approach on creative thinking skills and self-confidence.
\end{abstract}

Keywords—creative thinking skills, self-confidence, MEAs

\section{INTRODUCTION}

In the world of education, quality for human resources are needed in all aspects. Quality resources can advance science and technology. According to Darmadi [1] to advance science and technology required an understanding of mathematics science from an early age. Considering mathematics importance to develop world, it is apprehensive condition when we see the students who are less master mathematics for nowadays. This reality is described from the results of research which is conducted in 2012 by Organization Economic Corporation and Development (OECED) made The
Program for International Student Assessment (PISA) which is the result show that Indonesia is ranked 64 out of 65 countries.

Mathematics as one of basic science has an important and useful role for science and technology development. Mathematics that is taught in school act as role for training students to think logically, critically and practically, reasoning effectiveness, being scientific, disciplined, responsible, confident accompanied with faith. Due to its importance in students life, mathematics has to be placed on a science classroom as nature and technology cognition in the education curiculum and should be placed as one of students competence that must have at every education level starting from Primary School to High School [2]. One of the mathematical abilities that is expected to be developed by students is creative thinking skills. The 2013 curriculum stated creatively thinking ability is need to master for creating better technology in future, which means math has to be given for all learners to fit them up on logical, analytical, systematic, critical, creative and ability to work together [3]. Student creativity is one of factors that influence learning mathematics achievement. The student's low creativity is caused by one-direct learning process, emphasizing the student's cognitive aspects only, while the affective and psychomotor aspects of the students are ignored. Supriadi [4] obtained information from research that is conducted by Hans, Jellen of the University of Utah, United States and Klaus Urban of the University of Hannover Germany, writed that Indonesia has the lowest student's creativity compared to 8 other countries studied. Another cause of student's low learning result is passively teachers that has less attention for student's activity. The students only 
imitate what the teachers do as a result, and sometimes just manually follow the steps in book or follow teacher's example. Then students has no confidence for their answers and they always tend to copy others' answers. The low selfconfidence of students is indicated by the results of Mullis et, all study in TIMSS 2011 [5] which stated that only $14 \%$ of students have high self-esteem related to their mathematical ability on the international scale. While $45 \%$ of students included in avarage category and $41 \%$ of the rest included in the low category. The similar condition for students in Indonesia, where only $3 \%$ of students have high self-esteem in math, while $52 \%$ of students are included in moderate confidence category, and $45 \%$ of students are included in the category of students whose low self-confidence.

Wrong teacher's learning method which is applied to students could be as cause of student's experiencing learning difficulties as explained earlier that finally lead to low their ability of creative thinking and self-confidence on learning mathematic. Teachers practically using conventional model learning in the classroom. In conventional learning models, students have to listen lesson that is taught by the teacher, the discussion process still runs using this conventional model, but the student activity is not developed and the students just follow the instructions that is given by the teacher.

Learning model gives more flexibility for students for exploring while learning and can improve self-confidence of students is Model-Eliciting Activities (MEAs). MEAs are approaches that teach students to provide their own sollution model in solving problems. The model created mathematical sollution formula and make steps that can be used in solving mathematical problems. This approach requires students to form a group, then each student must solve math problem together to explore in conducting idea that is believed to solve math problems and determine the idea that is considered the truest and original which is required to be able to create their own models [6]. Learning using MEAs can essentially develop students' cognitive and affective abilities as base for developing the student's creative process. Learning using MEAs is based on situations that occur in the student's real life so it can stimulate student motivation and involvement in the learning process [7]. Lesh \& Thomas in his research shows that involving students with non-routine mathematical problems through learning using MEAs can encourage students to develop, create or find mathematical model [8]. Similarly, English [9] pointed out that the multifaceted nature of learning using MEAs makes it the right path, making it easier for students to learn many things, especially in solving problems with their routine scenarios. Learning MEAs also cultivate students in solving real problems creatively and teach students on how to apply mathematics to other situations [10].

\section{TEOTRICAL REVIEW}

\section{A. Creative Thinking Skills}

Creative thinking skills is the person ability to produce something new for himself, either in ideas forms or real works that are different from before. Something new here does not mean having to do a whole new piece of work that has never existed before, but can be a merge two or more existing concepts to be a unique one. Meanwhile, according to Saefudin
[11] in the creative thinking of a person will go through the stages of synthesizing ideas, build ideas, plan the application of ideas and apply these ideas to produce a new product. In line with the above opinion, Saefuddin also said that the product in question is creativity. Creative thinking is also a mathematical process that be used when we bring / emerge a new idea. Indicator of creative thinking ability is fluency, flexibility, originality, and elaboration.

\section{B. Self-Confidence}

Self-confidence is defined as a self-confidence that each individual has in his life, and how the individual views himself as a whole by referring to self-concept. Meanwhile, according to Willis [12] revealed that self-confidence is the belief that someone is able to overcome problems with the best situation and can provide something usable for others.

\section{Model-Eliciting Activities (MEAs) Approach}

The MEAs approach is a reality-based approach, works in small groups and presents a model to help students build problem solving and get students to apply an understanding of the mathematical concepts that they have learned. MEAs are ideally structured to assist students in solving real life-related problems so that students have strong mathematical construction. MEAs help the development of student thinking because students can create their own models to solve mathematical problems. Students do not need to be doubt for finding answers besides teacher explanation. To introduce MEAs, teachers do not need to model the algorithmic process to solve the problems undertaken in conventional learning steps.

The learning steps are:

a. students review information on matters relating to issues that should be provided by them,

b. students answer a preparedness question based on information about what is in the problem,

c. the teacher gives students problems and ensures that each group understands what is being asked,

d. then they try to solve the problem and present their model in front of the class [13].

\section{METHODOLOGY RESEARCH}

The type of this research is quasi-experimental research using pre test and post test control group design. The population in this study is all high school students in the city of Barus, Nort Sumatera precisely in SMA Negeri 1 Barus. Sampling technique used in this research is purposive sample technique. From the sampling result, we get $11^{\text {th }}$ grade-A class as experiment class and class $11^{\text {th }}$ grade-B as control class. The data in this study were collected by providing in essay test. The pre-test and post-test datas were calculated to find the normalized average gain values. Then from the calculation result of normalized average value gain done by hypothesis test calculation using Two Ways ANOVA using SPSS 17.0 for windows. 


\section{RESULT AND DISCUSSION}

The results showed that there was an increase in the creative thinking skills of students who were taught using the MEAs approach. It can be seen from the calculation table ANAVA 2 Path as follows:

TABLE I. ANOVA TEST RESULT IN IMPROVING STUDENT'S MATHEMATICS CREATIVE THINKING SKILLS BASED ON LEARNING

\begin{tabular}{|l|l|l|l|l|l|}
\hline \multicolumn{7}{|c|}{ Tests of Between-Subjects Effects } \\
\hline Dependent Variable:Creative_Thinking \\
\hline $\begin{array}{l}\text { Type III } \\
\text { Sum of } \\
\text { Squares }\end{array}$ & Df & $\begin{array}{c}\text { Mean } \\
\text { Square }\end{array}$ & F & Sig. \\
\hline Corrected Model & $.0312^{\mathrm{a}}$ & 3 & .104 & 7.579 & .000 \\
\hline Intercept & 15.749 & 1 & 15.749 & 1147.19 & .000 \\
\hline Learning & .252 & 1 & .252 & 18.345 & .000 \\
\hline Gender & .000 & 1 & .000 & .023 & .881 \\
\hline $\begin{array}{l}\text { Learning * } \\
\text { Gender }\end{array}$ & .052 & 1 & .052 & 3.768 & .057 \\
\hline Error & .824 & 60 & .014 & & \\
\hline Total & 16.976 & 64 & & & \\
\hline Corrected Total & 1.136 & 63 & & & \\
\hline a. R Squared $=.275($ Adjusted R Squared $=.239)$ \\
\hline
\end{tabular}

Based on table 1 involved that for the learning factor, obtained the value of $\mathrm{F}$ arithmetic of 18.345 and a significant value of 0.000 . Because the value is significantly smaller than the significant level limit of $0.05, \mathrm{H}_{\mathrm{o}}$ is rejected and $\mathrm{H}_{1}$ is accepted. Thus, it can be concluded that the improvement of the ability of creative thinking of students who taught learning using MEAs higher than the ability to think creatively mathematically students who taught learning using conventional learning.

The results of further research indicate that there is an increase in self-confidence questionnaire results of students taught by using the MEAs approach is higher than the results of questionnaires students who were taught using a conventional approach. The results of two paths ANAVA calculation can be seen in the table 2 below:

TABLE II. ANOVA TEST RESULT IN IMPROVING STUDENT'S SELF-CONFIDENCE BASED ON LEARNING

\begin{tabular}{|l|r|r|r|r|r|}
\hline \multicolumn{7}{|c|}{ Tests of Between-Subjects Effects } \\
\hline Dependent Variable: Self-Confidence \\
\hline Source & $\begin{array}{c}\text { Type III } \\
\text { Sum of } \\
\text { Squares }\end{array}$ & Df & $\begin{array}{c}\text { Mean } \\
\text { Square }\end{array}$ & \multicolumn{1}{c|}{ F } & Sig. \\
\hline Corrected Model & $.055^{\text {a }}$ & 3 & .018 & 2.701 & .054 \\
\hline Intercept & 11.404 & 1 & 11.404 & 1665.01 & .000 \\
\hline Learning & .046 & 1 & .046 & 6.750 & .012 \\
\hline Gender & .001 & 1 & .001 & .099 & .754 \\
\hline $\begin{array}{l}\text { Pembelajaran * } \\
\text { Learning }\end{array}$ & .010 & 1 & .010 & 1.490 & .227 \\
\hline Error & .411 & 60 & .007 & & \\
\hline Total & 11.866 & 64 & & & \\
\hline Corrected Total & .466 & 63 & & & \\
\hline a. R Squared $=.119$ (Adjusted R Squared $=.075)$ \\
\hline
\end{tabular}

Based on table 2 it can be seen that for the learning factor, the calculated $F$ value is 6.750 and the significant value is 0.012 . Since the value is significantly smaller than the significance level limit of 0.05 then $\mathrm{H}_{0}$ is rejected and $\mathrm{H}_{1}$ is accepted. Thus, it can be concluded that the increase of selfconfidence of students who are taught by using MEAs learning is higher than self-confidence of students who are taught using conventional learning.

Based on data analyzed in this study in accordance with research conducted by Lesh \& Doerr [14] also shows that the first aim of MEAs learning is to invite students to be able to create mathematical models in solving complex mathematical problems as to develop their mathematical creative thinking ability. Further Moore [15] in his research revealed that the use of MEAs has been proven to work very well in the classroom. The thoughts aspect of the MEAs allows teachers to understand what students think is when working on a problem. Teachers also can use MEAs to serve as a tool for the development of student learning processes that can improve students 'ability to understand complex situations to students' creative thinking skills [16]. The use of MEAs learning can finally help teachers to make students more independent, confident, more motivated and most importantly students are encouraged to be creative and imaginative in exploring to find solutions to problems that transcend the outcomes of conventional learning [17]. Wessels [18] also stated that the use of MEAs in the process of learning mathematics in schools can develop students' creativity that begins by expanding students' mathematical knowledge and establish a better understanding of how building students' mathematical creativity increases process.

Further research also obtained results that the application of MEAs can improve student self confidence. The results obtained by Jacobs \& Durandt [19] that the implication of the application of MEAs learning taught by lecturers to the development of the competence of prospective teachers (read: students) can build teachers' self-confidence gradually. Papageorgiou [20] also argued that the mathematical modeling learning (MEAs) can improve students 'self-confidence and students' attitudes toward the learning of mathematics itself. Blumm \& Niss [21] also argue that students can solve mathematical problems in their own way through mathematical modeling (MEAs) to improve confidence and leadership. Student self-confidence in the learning process can be developed through the activities undertaken in the learning process. In the learning process of MEAs, students are required to be active in solving real problems that are around the student's life. Doruk also expressed a similar opinion that the real-life context presented in the problems given in the MEAs learning process contributed to the increase in selfconfidence for the students who undertook the activity. Furthermore, Doruk also obtained interview results conducted after the application of MEAs, where students showed a positive attitude towards activities that fit the context of everyday life. This is supported by Maab's which recognizes that there is a relationship between MEAs and real issues that can produce a positive attitude [22]. Because MEAs and real problems produce positive attitudes toward mathematics learning, the increase in self-confidence and the development 
of students' positive attitudes is an affective advantage of the learning process of MEAs [23].

From the above explanation, it is clear that the learning of MEAs has a significant contribution in developing students' self-confidence. The learning of MEAs also fosters students' positive attitudes toward mathematical learning which has been a frightening thing. Through the stages of activity on the MEAs, students are more confident in solving real problems that they solve in their own way. Through MEAs learning students are invited to solve real problems in groups, but the impact of group activity in MEAs reflects on each individual student [24].

\section{CONCLUSION}

From the results of this study can be concluded that the application of MEAs in learning mathematics in the classroom has a good impact on improving student learning outcomes, especially the ability of creative thinking and self-confidence for high school students. This is caused by the syntax of the MEAs approach which gives a positive effect on the ability of creative thinking and self confidence of students. Activities in the MEAs approach force students to be more active in the learning process, leading students creativity and even enhance their sense of confidence.

\section{REFERENCES}

[1] N.Marliani, "Peningkatan Kemampuan Berpikir Kreatif Matematis Siswa Melalui Model Pembelajaran Missouri Mathematics Project (MMP)", Jurnal Formatif, 2015, Vol. 5, No. 1, pp.14-25

[2] R. Ramadhani, "Pengembangan Perangkat Pembelajaran Matematika yang Berorientasi pada Model Problem Based Learning", KREANO, Jurnal Matematika Kreatif-Inovatif, 2016, Vol. 7, No. 2, pp.116-112

[3] S.A. Aziz, "Pengembangan Kemampuan Berpikir Kreatif Siswa Dalam Pembelajaran Matematika dengan Pendekatan Pendidikan Matematika Realistik Indonesia (PMRI)", Jurnal Al-Bidayah , 2012, Vol. 4, No.1, pp. 37-48

[4] R. Rahman, "Hubungan Antara Self-Concept Terhadap Matematika dengan Kemampuan Berpikir Kreatif Matematika Siswa. Infinity", Jurnal Ilmiah Program Studi Matematika STKIP Siliwangi Bandung, 2012, Vol. 1, No.1, pp.19-30

[5] I.V.S. Mullis, M.O.Martin, P. Foy, and A.Arora, TIMSS 2011: International Results in Mathematics., United States: TIMSS \& PIRLS International Study Center, pp. 1-491

[6] I. Siregar, "Menerapkan Pembelajaran Matematika Menggunakan Model-Elicting Activities untuk Meningkatkan Self-Confidence Siswa SMP”, Himpunan Matematika Indonesia KNPM V-Juni 2013

[7] T. Gilat, and M. Amit, "Exploring Young Students Creativity: The Effect of Model Eliciting Activities". PNA, 2013, Vol. 8, No. 2, pp.5159
[8] R. Lesh, and F. Thomas, Modeling Students' Mathematical Modeling Competencies. Springer Sciences +Business Media, 2010

[9] L. English, Mathematical Modelling with Young Learners. In S. Lamon, W. Parker, \& S. Houston (Eds.), Mathematical Modelling: A Away of Life, Chichester: Horwood Publishing, 2007

[10] R. S. Asempapa, "Mathematical Modelling: Essential for Elementary and Middle School Students", Journal of Mathematics Education, 2015, Vol.8, No.1, pp.16-29

[11] A. A. Saefudin, "Pengembangan Kemampuan Berpikir Kreatif Siswa dalam Pembelajaran Matematika dengan Pendekatan Pendidikan Matematika Realistik Indonesia (PMRI)", Al-Bidayah, 2012, Vol.4, No.1, pp.37-48

[12] A. Martyanti, "Membangun Self-Confidence Siswa dalam Pembelajaran Matematika dengan Pendekatan Problem Solving", Prosiding Seminar Nasional Matematika dan Pendidikan Matematika FMIPA UNY, 2013

[13] S. A. Chamberlin, and S. M. Moon, "Model-Elicting Activities as a Tool to Develop and Identify Creatively Gifted Mathematicians", The Journal of Secondary Gifted Education (JSGE), 2005, Vol. XVII, No.1, pp.37 47

[14] R. Lesh, Doerr, and M. Helen, "Beyond Constructivism, Models and Modelling Perspectives on Mathematics Problem Solving, Learning and Teaching", ZDM, 2003, Vol.35, No.6

[15] T. J. Moore, "Model-Eliciting Activities: A Case-Based Approach for Getting Students Interested in Material Science and Engineering”, Journal of Materials Education, 2008

[16] L. J. Shuman, "The Model Eliciting Activity (MEA) Construct: Moving Engineering Education Research Into The Classroom", Proceedings of the 9th Biennial ASME Conference on Engineering Systems Design and Analysis-ESDA08, 2008

[17] N. G. Mousoulides, "Mathematical Modeling for Elementary and Secondary School Teachers", Learning through Mathematical Modeling: LEMA Project presented is co-funded by the European Union, 2006, unpublished

[18] H. Wessels, "Levels of Mathematical Creativity in Model-Eliciting Activities", Journal of Mathematical Modelling and Aplication, 2014 Vol.1, No. 9, pp.22-40

[19] G. J. Jacobs, and R. Durandt, "Attitudes of Pre-Service Mathematics Teachers towards Modelling: A South African Inquiry", EURASIA Journal of Mathematics Science and Technology Education, 2017, Vol.13, No.1, pp.61-84

[20] G. Papageorgiou, The Effect of Mathematical Modeling on Students' Affect, Thesis Mathematics and Science Education, AMSTEL InstituteUniversiteit van Amsterdam, 2009

[21] W. Blum, and M. Niss, "Applied Mathematical Problem Solving, Modelling, Applications, and Links to Other Subjects-State, Trends and Issues in Mathematics Instructions", Educational Studies in Mathematics, 1991, Vol.22, pp.37-68

[22] B. K. Doruk, "Realistic Real World Contexts: Model Eliciting Activities", Paper was presented and discussed at the Turkish Computer and Mathematics Education Symposium in Trabzon, Turkey 20-22 June 2013

[23] H. C. Celik, "Mathematical Modelling Research in Turkey: A Content Analysis Study", Educational Research and Reviews, 2017, Vol.12, No.1, pp.19-27

[24] C. K. Baker, and T. M. Galanti, "Integrating STEM in Elementary Classrooms Using Model-Eliciting Activities: Responsive Profesional Development for Mathematics Coaches and Teachers", International Journal of STEM Education, 2017, Vol.4, No.10 